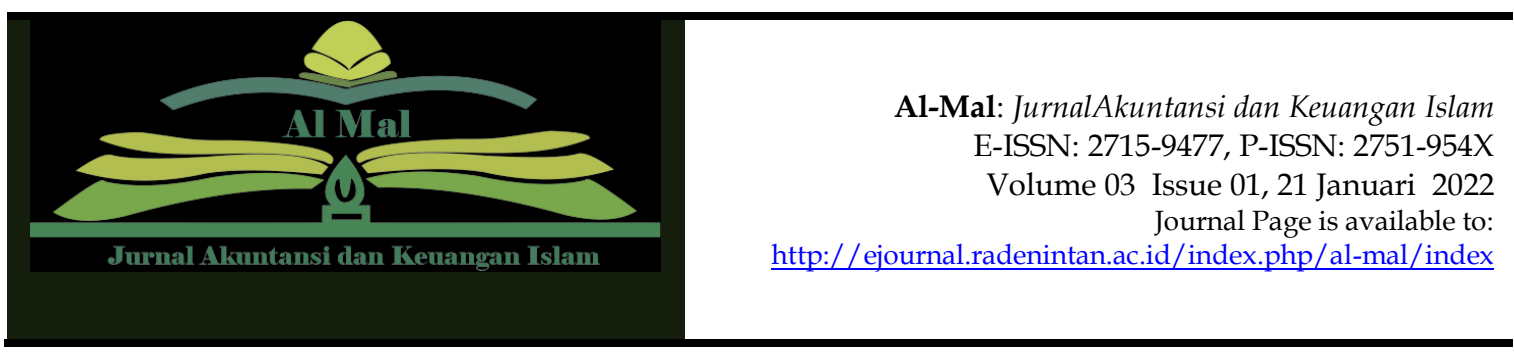

\title{
Analisis Pengaruh Pengendalian Internal, Kompetensi, Upah, Dan Lingkungan Kerja Terhadap Produktivitas Kerja Karyawan Pada Perusahaan Entitas Syariah
}

\author{
Bramsyah $^{1 *}$, Yulistia Devi ${ }^{2}$, Supaijo $^{3}$
}

$1^{*}, 2,3$ Departement of Economics, Faculty of Economics and Business, Universitas Islam Negeri Raden Intan Lampung, Indonesia

\begin{tabular}{l}
\hline \multicolumn{1}{c}{ ARTICLE INFO } \\
\hline Article history: \\
Received 18-01-2022 \\
Revised 20-01-2022 \\
Accepted 21-01-2022 \\
Available 21-01-2022 \\
Revised (1) 24-07-2022 \\
Accepted 31-07-2022 \\
Revised Available 01-08-2022 \\
\hline Kata Kunci: \\
Pengendalian Internal, Kompetensi, \\
Upah, Lingkungan Kerja, \\
Produktivitas Kerja Karyawan \\
\hline
\end{tabular}

Paper type: Research paper

Please cite this article: Bramsyah, B., Devi, Y., Supaijo, S. "Analisis Pengaruh Pengendalian Internal, Kompetensi, Upah, Dan Lingkungan Kerja Terhadap Produktivitas Kerja Karyawan Pada Perusahaan Entitas Syariah

(Studi Kasus Pada PT BPRS Bandar Lampung)" Al-Mal: Jurnal Akuntansi dan Keuangan Islam [ONLINE], Volume 03 Number 01 (Januari 21, 2022)

Cite this document:

Al-Mal 2th edition

*Corresponding author e-mail: bramsyah@gmail.com

\begin{abstract}
ABSTRAK
Tujuan Penelitian ini untuk mengetahui pengaruh pengendalian internal, kompetensi, upah, dan lingkungan kerja terhadap produktivitas kerja karyawan pada PT BPRS Bandar Lampung secara parsial maupun secara simultan. Penelitian ini termasuk dalam penelitian lapangan (Field Research), dengan menggunakan metode pendekatan kuantitatif. Metode analisis data menggunakan analisis regresi linear berganda, dengan menggunakan bantuan software IBM Statistik SPSS 17. Hasil penelitian menunjukan bahwa pengendalian internal berpengaruh signifikan terhadap produktivitas kerja karyawan. Kompetensi berpengaruh signifikan terhadap produktivitas kerja karyawan. Upah berpengaruh signifikan terhadap produktivitas kerja karyawan. Dan lingkungan kerja berpengaruh signifikan terhadap produktivitas kerja karyawan. Keterbatasan pada penelitian yaitu wilayah pengamatan masih di BPRS Kota Bandar Lampung sehingga membuka peluang bagi peneliti selanjutnya untuk memperluar wilayah pengamatan dalam penelitian. Implikasi penelitian yaitu kompetensi karyawan dalam suatu lembaga/institusi/perusahaan haruslah baik sesuai nilai-nilai islam yaitu karyawan harus amanah dan jujur dalam bekerja memiliki hubungan yang baik antara atasan dan bawahan. Sehingga hal-hal tersebut dapat meningkatkan produktivitas kerja karyawan.
\end{abstract} Al-Mal with CC BY license. Copyright $\subset$ 2022, the author(s) 


\begin{abstract}
The purpose of this study was to determine the effect of internal control, competence, wages, and work environment on the work productivity of employees at PT BPRS Bandar Lampung partially or simultaneously. This research is included in the field research (Field Research), using a quantitative approach method. The data analysis method used multiple linear regression analysis, using the help of IBM Statistics software SPSS 17. The results showed that internal control had a significant effect on employee productivity. Competence has a significant effect on employee work productivity. Wages have a significant effect on employee work productivity. And the work environment has a significant effect on employee productivity. The limitation of the research is that the observation area is still in the BPRS Bandar Lampung City, thus opening up opportunities for further researchers to expand the observation area in the study. The implication of the research is that the competence of employees in an institution/institution/company must be good according to Islamic values, namely employees must be trustworthy and honest in their work and have a good relationship between superiors and subordinates. So that these things can increase employee productivity.
\end{abstract}

\title{
Keyword: Information dissemination, SAK ETAP, Human Resources Competence, Accountability, Financial Reports.
}

\section{PENDAHULUAN}

Pertumbuhan dan perkembangan industri perbankan syariah di Indonesia sangatlah cepat dari waktu ke waktu. Kondisi industri perbankan syariah di Indonesia telah mengalami banyak perubahan. Selain disebabkan faktor eksternal, pertumbuhan dan perkembangan perbankan syariah juga tidak terlepas dari pengaruh perkembangan internal perbankan syariah itu sendiri seperti perkembangan segi fisik maupun non fisik. Perkembangan yang sangat cepat tersebut perlu diikuti dengan pengelolaan manajemen yang baik.

Pengelolaan manajemen sumber daya manusia (SDM) merupakan salah satu hal yang harus dioptimalkan. Dalam hal ini, pengelolaan manajemen SDM adalah suatu perencanaan, pengorganisasian, pelaksanaan dan pengawasan terhadap pengadaan, pengembangan, pemberian balas jasa, pengintegrasian, pemeliharaan dan pemisahan tenaga kerja dalam rangka mencapai tujuan organisasi (Riawati, dkk, 2016 : 121). Oleh karena itu, sumber daya manusia masih menjadi sorotan dan tumpuan bagi perusahaan untuk tetap dapat bertahan pada era globalisasi. 
Karyawan adalah sumber daya yang memberikan kontribusi besar terhadap perusahaan atau institusi. Tanpa adanya karyawan yang bekerja disebuah perusahaan atau instansi, maka perusahaan atau instansi tersebut akan sangat sulit mencapai tujuannya. Oleh karena itu, karyawan memiliki kedudukan yang strategis dalam mengembangkan dan memajukan perusahaan dengan produktivitas kerjanya.

Produktivitas dapat diartikan sebagai ukuran efisiensi produktif, yaitu perbandingan antara keluaran/output (barang dan jasa yang dihasilkan) dengan masukan / input (sumber daya yang digunakan untuk menghasilkan output). Masukan/input sering dibatasi dengan tenaga kerja, sedangkan keluaran/ output diukur dalam satuan fisik, bentuk dan nilai. Tingginya angka produktivitas merupakan impian setiap perusahaan atau instansi. Hal ini tentu akan berdampak pada peningkatan pendapatan perusahaan atau instansi yang merupakan tujuan dan cita-cita perusahaan.

Untuk mengetahui produktivitas kerja karyawan sudah baik atau tidaknya di PT BPRS Bandar Lampung, dapat dilihat dari indikator produktivitas kerja yaitu indikator meningkatkan hasil yang dicapai dan indikator efisiensi, indikator tersebut bisa dilihat dari data tingkat pendapatan/laba yang dihasilkan dan diperoleh setiap tahunnya oleh PT BPRS Bandar Lampung. Data pendapatan tersebut bisa dilihat di laporan keuangan yang telah dipublikasikan di website PT BPRS Bandar Lampung.

Dalam menilai produktivitas kerja suatu perusahaan, maka salah satu aspek yang dapat diambil adalah rasio profitabilitas. Hal ini dikarenakan Rasio profitabilitas adalah ukuran dari penilaian kinerja perusahaan yang menunjukkan hasil akhir dari sejumlah peraturan dan keputusan yang diambil oleh manajemen perusahaan. Rasio profitabilitas disebut juga dengan rasio efisiensi. Rasio ini digunakan untuk mengukur efisiensi penggunaan aktiva perusahan. Rasio profitabilitas perbankan dapat dilihat dari Return On Asset (ROA). Return On Asset (ROA) adalah rasio yang menggambarkan kemampuan perusahaan untuk menghasilkan keuntungan dari setiap suatu rupiah aset 
yang digunakan. Jadi kita dapat melihat apakah perusahaan efisien dalam memanfaatkan asetnya dalam kegiatan operasional perusahaan. Berikut adalah rasio profitabilitas pada PT BPRS Bandar Lampung (PT BPRS Bandar Lampung, 2021).

PT Bank BPRS Bandar Lampung memiliki aset yang cukup besar, akan tetapi dalam merencanakan dan dan mengelola aset dan liabilitas masih kurang maksimal. Hal ini terlihat dari rasio Return On Asset (ROA) yang hanya berkisar 2,3\% - 2,37\% saja, belum mampu melampaui standar Return On Asset (ROA) yang baik sebesar 5,98\%. Hal ini menunjukkan bahwa kinerja yang dilakukan masih belum efektif karena pada dasarnya rasio Return On Asset (ROA) digunakan untuk menilai efisien perusahaan dalam memanfaatkan asetnya dalam kegiatan operasional perusahaan.

Dalam suatu perusahaan seringkali hanya menuntut produktivitas kerja yang tinggi kepada para karyawan, tanpa melihat faktorfaktor yang mempengaruhinya. Banyak hal yang dapat mempengaruhi produktivitas kerja karyawan, untuk itu perusahaan harus berusaha menjamin agar faktor-faktor yang berkaitan dengan produktivitas tenaga kerja dapat dipenuhi secara maksimal.

Salah satu faktor yang dapat mempengaruhi produktivitas kerja karyawan adalah faktor pengendalian internal perusahaan. Pengendalian internal adalah proses yang dirancang untuk memberikan kepastian yang layak mengenai pencapaian tujuan manajemen tentang reliabilitas pelaporan keuangan, efektivitas dan efisiensi operasi, dan kepatuhan terhadap hukum dan peraturan yang berlaku. Perusahaan menggunakan pengendalian internal untuk mengarahkan operasi dan mencegah penyalahgunaan sistem. Pimpinan perusahaan menyadari pentingnya manajemen yang didalamnya mengatur tentang pengendalian internal sebagai alat berharga dalam menunaikan tanggung jawabnya (Sumbulatin Miatuhabbah, 2018 : 27). Untuk mengetahui pengendalian internal baik atau tidaknya di PT BPRS Bandar Lampung, dapat dilihat dari indikator-indikator pengendalian internal yaitu lingkungan 
pengendalian, aktivitas pengendalian, aktivitas pengawasan, serta informasi dan komunikasi.

Faktor lain yang dapat mempengaruhi produktivitas kerja karyawan adalah kompetensi. Kompetensi adalah faktor utama yang harus dimiliki oleh karyawan dalam melaksanakan pekerjaannya. Dengan kompetensi yang baik maka akan dapat membantu para karyawan di dalam menyelesaikan pekerjaannya sehingga dapat meningkatkan produktivitas kerja karyawan. Kinerja sumber daya manusia (SDM) yang berkualitas tentu sangat erat kaitannya dengan pendidikan dan pelatihan yang pernah dijalani. Pendidikan dan pelatihan yang berkualitas baik akan memiliki peluang lebih besar menghasilkan SDM yang berkualitas tinggi (Tri Wikaningrum, 2011 : 100). Untuk mengetahui kompetensi karyawan baik atau tidaknya di PT BPRS Bandar Lampung, dapat dilihat dari indikator-indikator kompetensi yaitu pengetahuan dan keahlian karyawan.

Faktor lain yang dapat mempengaruhi produktivitas kerja karyawan adalah upah kerja karyawan. Hal ini dikarenakan untuk mencapai produktivitas kerja karyawan yang tinggi, perusahaan perlu memperhatikan masalah upah kerja yang merupakan faktor pendorong dalam mencapai produktivitas kerja. Dengan produktivitas yang tinggi akan dapat menjamin kelangsungan hidup perusahaan. Upah adalah imbalan berupa uang dari pemilik usaha kepada pekerja karena telah berjasa menghasilkan barang produksi/jasa yang telah dikerjakan.

Faktor lain yang dapat mempengaruhi produktivitas kerja karyawan lainnya adalah faktor lingkungan kerja karyawan. Lingkungan Kerja adalah kehidupan sosial, psikologi dan fisik dalam perusahaan yang berpengaruh terhadap pekerja dalam melakukan tugasnya. Lingkungan kerja karyawan juga sangat penting dalam mempengaruhi produktivitas kerja karyawan. Semakin baik, nyaman dan kondusif lingkungan kerjanya, maka semakin meningkat pula produktivitas kerja para karyawan. Oleh karena itu setiap perusahaan perlu memahami secara mendalam mengenai lingkungan baik secara langsung 
maupun tidak langsung sehingga produktivitas pekerja dapat mencapai titik yang maksimal. Untuk mengetahui lingkungan kerja baik atau tidaknya di PT BPRS Bandar Lampung, dapat dilihat dari indikator-indikator lingkungan kerja yaitu kondisi kerja, perlengkapan kerja dan pelayanan kepada pegawai/karyawan.

1. Produktivitas Kerja

Kinerja Produktivitas dapat diartikan sebagai perbandingan antara keluaran/output (barang dan jasa yang dihasilkan) dengan masukan/input (sumber daya yang digunakan untuk menghasilkan output).

Menurut Nanang Fattah dalam Tjutju Yuniarsih menyimpulkan bahwa dalam konsep produktivitas kerja adalah keefektifan dan efisiensi dalam penggunaan berbagai sumber daya, sedangkan dalam pengertian perilaku, produktivitas merupakan sikap mental yang senantiasa berusaha untuk berkembang (Budi Rismayadi, 2015 : 3).

2. Pengertian Pengendalian Internal

Dalam Menurut Hery pengendalian internal adalah seperangkat kebijakan dan prosedur untuk melindungi aset atau kekayaan perusahaan dari segala bentuk tindakan penyalahgunaan, menjamin tersedianya informasi akuntansi perusahaan yang akurat, serta memastikan bahwa semua ketentuan (peraturan) hukum/undang-undang serta kebijakan manajemen telah dipatuhi atau dijalankan sebagaimana mestinya oleh seluruh karyawan perusahaan (Hery, 2014 : 11).

Menurut Committe Of Sponsoring Organization Of The Treadway Commission (COSO) pengendalian internal merupakan rangkaian tindakan yang mencangkupkan keseluruhan proses dalam organisasi (Wiratna Sujarweni, $2015: 70)$.

Menurut Committee of Sponsoring Organization of the Treadway Commission (COSO), pengendalian internal satuan usaha terdiri atas komponen- komponen Lingkungan Pengendalian, Penilaian Resiko, Informasi dan Komunikasi, Aktivitas Pengendalian dan Pemantauan (Putri \& Endiana, 2020). 
Menurut (Risnawati \& Retnoningsih, 2020), kinerja karyawan dapat berjalan dengan baik apabila ada pengendalian internal dari manajemen. Pengendalian intern diperlukan dalam perusahaan agar kinerja perusahaan dapat berjalan secara efektif dan efisien dalam mencapai tujuan yang diharapkan.

\section{Pengertian Kompetensi}

Menurut Wibowo menjelaskan kompetensi adalah suatu kemampuan untuk melaksanakan atau melakukan suatu pekerjaan atau tugas yang dilandasi atas keterampilan atau pengetahuan serta didukung oleh sikap kerja yang dituntut oleh pekerjaan tersebut, dengan demikian terdapat suatu kesepakatan umum mengenai elemen kompetensi, yaitu terdiri dari pengetahuan (knowledge), keterampilan (skill) dan perilaku (personal attributes). Secara umum, kompetensi adalah tingkat keterampilan, pengetahuan, dan tingkah laku yang dimiliki oleh seorang individu dalam melaksanakan tugas yang dibebankan kepadanya dalam organisasi (Wibowo, 2017 : 98-99).

Menurut Michael Armstrong yang membedakan pengertian competence dan competency. Competence menggambarkan apa yang dibutuhkan seseorang agar dia mampu melaksanakan pekerjaanya dengan baik. Pengertian Competence ini memberikan perhatian pada akibat (effect) dari usaha (effort). Dan pada output (keluaran) dari input (masukan). Selanjutnya, kata competency mengacu pada dimensi-dimensi perilaku sehingga sering disebut kompetensi perilaku (behavioral competencies) karena dimaksudkan untuk menggambarkan bagaimana orang-orang berperilaku ketika mereka melakukan perannya dengan baik.

Dari beberapa pengertian dari para ahli diatas, maka kompetensi adalah karakteristik dasar yang dimiliki oleh seseorang yang dapat menciptakan kinerja yang baik dalam melakukan pekerjaan yang menhadi tanggung jawabnya (Rosmaini \& Tanjung, 2019). Menurut (Saputra et al., 2016) kompetensi merupakan suatu faktor yang mempengaruhi disiplin kerja karyawan karena apabila pekerjaan yang dibebankan kepada seorang 
karyawan sesuai dengan kemampuan karyawan yang bersangkutan, maka dia akan bekerja dengan sungguh-sungguh dan disiplin dalam mengerjakannya. Tetapi apabila pekerjaan itu di luar kemampuannya, maka kesungguhan dan kedisiplinan karyawan akan rendah.

Menurut Hutapea dan Thoha dalam (Syahputra \& Tanjung, 2020), faktor-faktor yang mempengaruhi kompetensi, antara lain: Pengendalian Diri (Self Control), Kepercayan Diri (Self Confidence), Fleksibilitas (Flexibility) dan Membangun Hubungan (Relationship Building). Sedangkan, indikator kompetensi, diantaranya adalah : 1) Keyakinan dan nilai-nilai, 2) Keterampilan, 3) Pengalaman, 4) Karakteristik Kepribadian, 5) Motivasi, 6) Kemampuan intelektual, 7) Budaya organisasi.

4. Pengertian Upah

Upah sangat besar pengaruhnya terhadap tenaga kerja dalam menjalankan tugasnya dan jaminan terhadap kelangsungan hidup dirinya sendiri dan keluarganya. Upah merupakan harga untuk jasa-jasa yang telah diberikan seseorang kepada orang lain. Upah merupakan suatu penerimaan sebagai imbalan dari pimpinan perusahaan kepada tenaga kerja untuk suatu pekerjaan atau jasa yang telah dan akan dilakukan (Mohammad Kanzunnudin, $2017: 13)$.

Menurut Dewan Penelitian Perupahan Nasional (DPPN) memberikan pengertian upah yaitu penerimaan sebagai suatu imbalan dari pemberi kerja kepada penerima kerja untuk suatu pekerjaan atau jasa yang telah dan akan dilakukan, berfungsi sebagai jaminan kelangsungan kehidupan yang layak bagi manusia dan produksi dinilai dalam bentuk uang yang ditetapkan menurut suatu persetujuan undang-undang dan peraturan dan dibayarkan atas dasar perjanjian kerja antara pemberi kerja dan penerima kerja (Askimin Zainal, 2006 :20). 


\section{Pengertian Lingkungan Kerja}

Menurut Alex S. Nitisemito, Lingkungan kerja merupakan segala sesuatu yang ada sekitar pekerja yang dapat mempengaruhi dirinya dalam menjalankan tugas-tugas yang dibebankan (Alex S. Nitisemito, 2015 : 38).

Menurut Danang Sunyoto menyatakan Lingkungan kerja merupakan bagian komponen yang sangat penting di dalam karyawan melakukan aktivitas bekerja. Pengertian lingkungan kerja di sini adalah sesuatu yang ada di sekitar para pekerja dan yang dapat mempengaruhi dirinya dalam menjalankan tugastugas yang dibebankan, misalnya seperti ruang kerja yang nyaman dan aman, kebersihan, penerangan dan lain - lain (Danang Sunyoto, 2012 : 43).

\section{METODOLOGI PENELITIAN}

Penelitian menggunakan metode pendekatan kuantitatif. Metode kuantitatif dapat diartikan sebagai metode penelitian yang berlandaskan pada filsafat positivisme, digunakan untuk meneliti di populasi atau sampel tertentu, pengumpulan data menggunakan instrumen penelitian, analisis data bersifat kuantitatif/statistik dengan tujuan menguji hipotesis yang telah ditetapkan.

Pada penelitian skripsi ini penulis menggunakan jenis penelitian lapangan (field research), yang dimana penelitian lapangan (field research) adalah penelitian dimana data diperoleh dari lapangan secara langsung dari sumbernya, sehingga sumber data dalam penelitian lapangan adalah sumber primer. Dan pada penelitian ini bersifat asosiatif yaitu untuk mencari hubungan atau pengaruh antara satu variabel dengan variabel yang lain.

Data yang digunakan pada penelitian ini adalah data primer dan data sekunder, data primer diperoleh dari kuesioner dan wawancara, sedangkan data sekunder diperoleh melalui dokumentasi. Populasi dalam penelitian ini sebanyak 30 responden, dan sampel sebanyak 30 responden dengan menggunakan metode sampel jenuh. Metode analisis data menggunakan analisis regresi linear berganda, dengan menggunakan bantuan software IBM Statistik SPSS 17. 


\section{HASIL DAN PEMBAHASAN}

Entitas syariah merupakan suatu entitas atau organisasi yang berbadan hukum yang dalam kegiatan usahanya berlandaskan prinsip syariah. PT BPRS Bandar Lampung merupakan salah satu bentuk entitas syariah yang masih eksis dalam melakukan kegiatan operasional usahanya. Dalam suatu perusahaan seringkali hanya menuntut produktivitas kerja yang tinggi kepada para karyawan, tanpa melihat faktor-faktor yang mempengaruhinya. Banyak hal yang dapat mempengaruhi produktivitas kerja karyawan, untuk itu perusahaan harus berusaha menjamin agar faktor-faktor yang berkaitan dengan produktivitas tenaga kerja dapat dipenuhi secara maksimal. Adapun pembahasan mengenai variabel-variabel yang dapat mempengaruhi produktivitas kerja seperti Pengendalian Internal, Kompetensi, Upah dan Lingkungan Kerja akan dijelaskan berdasarkan pada hasil uji secara parsial, sebagai berikut :

1. Pengaruh Pengendalian Internal terhadap Produktivitas Kerja Karyawan di PT BPRS Bandar Lampung

Hasil Suatu perusahaan entitas syariah yang telah berjalan, sebaiknya selalu memantau seluruh kegiatan operasionalnya. Dibutuhkan sebuah pengendalian dengan tujuan membantu memantau aktivitasaktivitas operasional usahanya. Berdasarkan teori menurut Tugiman yang mengemukakan bahwa pengendalian internal adalah suatu fungsi penilaian yang independen dalam suatu organisasi untuk menguji atau mengevaluasi kegiatan organisasi yang dilaksanakan. Dengan adanya pengelolaan dan penerapan pengendalian internal yang baik maka suatu perusahaan akan lebih mudah dalam pencapaian tujuannya. Penerapan sistem pengendalian internal secara baik yang diharapkan dapat meningkatkan produktivitas kinerja karyawan (Hiro Tugiman, 2006 : 27). 
Hipotesis pertama dalam penelitian ini adalah "pengendalian internal berpengaruh secara signifikan terhadap produktivitas kerja karyawan". Hasil pengujian hipotesis menunjukkan bahwa nilai variabel pengendalian internal memiliki nilai signifikan 0,020 yang berarti lebih kecil dari 0,05 (sign < 0,05), sehingga dapat disimpulkan bahwa pengendalian internal berpengaruh signifikan terhadap produktivitas kerja karyawan di PT BPRS Bandar Lampung dan $\mathrm{Ha}_{1}$ diterima. Hasil penelitian ini sejalan dengan penelitian yang dilakukan oleh Dini Widyawati dan Putri Nurmala yang menyatakan bahwa sistem pengendalian internal berpengaruh terhadap kinerja karyawan dengan nilai signifikan yang lebih kecil dari 5\% atau 0,05 ((Dini Widyawati dan Putri Nurmala, 2019 : 67-75). Selain itu, penelitian ini didukung oleh penelitian lain yang dilakukan oleh (Suwarto \& Suharto, 2014) yang menyatakan bahwa pengendalian internal berpengaruh secara signifikan terhadap produktivitas pegawai, karena internal merupakan suatu strategi agar pegawai lebih memahami dan mengerti dari hasil yang dicapainya. Penelitian oleh (Sunarty, 2015) juga menyatakan bahwa pengendalian internal berpengaruh signifikan terhadap kinerja karyawan. Hal ini mengindikasikan bahwa metode, kebijakan, dan pengawasan bentuk dari pengendalian internal yang mempengaruhi kinerja karyawan. Adapun, penelitian yang dilakukan oleh (Bazighoh \& Sari, 2019) dalam hasil penelitiannya menyatakan bahwa pemahaman tentang pengendalian internal yang berjalan dengan efektif dan efisien, secara optimal, akan membawa dampak yang baik pada kinerja karyawan, terutama pada karyawan bidang keuangan perusahaan, untuk menghasilkan kinerja yang semakin baik. Dengan demikian, dapat disimpulkan bahwa pemahaman tentang pengendalian internal berdampak bagi kinerja karyawan.

PT BPRS Bandar Lampung sudah baik dalam menerapkan sistem pengendalian internal. Hal ini sesuai dengan hasil wawancara dengan Bapak Marsono, S.E selaku Wakil Direktur PT BPRS Bandar Lampung yang 
menyatakan bahwa, "PT BPRS Bandar Lampung sudah memiliki komite pengawas baik internal maupun eksternal yang bertugas memberi rekomendasi atau saran dan mengawasi jalannya kinerja operasional PT BPRS Bandar Lampung. Selain itu juga sudah ada SOP yang mengatur segala hal untuk menghindari berbagai tindakan fraud yang bisa terjadi dan juga dapat mendukung kinerja PT BPRS Bandar Lampung. Dan hubungan informasi dan komunikasi antara manajemen dan karyawan berjalan dengan baik termasuk terbuka dengan ide, saran, dan kritik dari karyawan".

Berdasarkan Analisis Regresi Linear Berganda, nilai koefisien regresi Pengendalian Internal $\left(X_{1}\right)$ adalah sebesar 0,409 dan menunjukkan arah koefisien regresi positif (searah) antara Pengendalian Internal dan Produktivitas Kerja. Artinya setiap kenaikan 1 satuan variabel Pengendalian Internal dan variabel lainnya dianggap konstan maka akan menaikkan nilai Produktivitas Kerja sebesar 0,409.

2. Pengaruh Kompetensi terhadap Produktivitas Kerja Karyawan di PT BPRS Bandar Lampung

Berdasarkan teori menurut Wibowo menjelaskan bahwa kompetensi adalah suatu kemampuan untuk melaksanakan atau melakukan suatu pekerjaan atau tugas yang dilandasi atas keterampilan atau pengetahuan serta didukung oleh sikap kerja yang dituntut oleh pekerjaan tersebut, dengan demikian terdapat suatu kesepakatan umum mengenai elemen kompetensi, yaitu terdiri dari pengetahuan (knowledge), keterampilan (skill) dan perilaku (personal attributes) (Wibowo, 2017 : 98-99).

Hipotesis kedua dalam penelitian ini adalah "kompetensi berpengaruh secara signifikan terhadap produktivitas kerja karyawan". Hasil pengujian hipotesis menunjukkan bahwa nilai variabel kompetensi memiliki nilai signifikan 0,003 yang berarti lebih kecil dari 0,05 (sign < 0,05), sehingga dapat disimpulkan bahwa kompetensi berpengaruh signifikan terhadap produktivitas kerja karyawan di PT BPRS Bandar Lampung dan $\mathrm{Ha}_{2}$ diterima. Hasil penelitian ini sejalan dengan penelitian yang dilakukan oleh Falentina K. G. Rani, Linda Lambey, dan Sherly Pinatik yang 
menyatakan hasil kompetensi berpengaruh terhadap produktivitas kerja karyawan bagian akuntansi di PT Bank Mandiri (Persero) Tbk Manado karena nilai $\mathrm{t}$ hitung 3,629 > t tabel 2,037 dan nilai signifikansi 0,001 <0,05 (Falentina K. G. Rani, Linda Lambey, dan Sherly Pinatik, 2018 : 41-51). Selain itu, penelitian lain oleh (Prayogi et al., 2019), (Pramularso, 2018) dan (Ardiansyah \& Sulistiyowati, 2018) juga menyatakan bahwa kompetensi berpengaruh positif dan signifikan terhadap kinerja karyawan yang berarti kompetensi menjadi salah satu bagian penting yang dapat meningkatkan kinerja karyawan, semakin meningkatnya kompetensi karyawan maka akan berdampak pada peningkatan kinerja karyawan.

PT BPRS Bandar Lampung telah memiliki kompetensi karyawan yang cukup baik guna menunjang kinerja yang produktif. Hal ini sesuai dengan hasil wawancara dengan ibu Yanti sebagai salah satu nasabah PT BPRS Bandar Lampung yang menyatakan bahwa, "karyawan PT BPRS Bandar Lampung sudah baik dalam memberikan pelayanan kepada nasabah, baik secara pengetahuan karyawan dapat menjelaskan secara jelas dan baik dalam memberikan pelayanan, dan dapat bekerja secara baik. Hal ini tentunya merupakan sinyal yang menandakan karyawan memiliki pengetahuan dan keahlian yang baik dalam memberi pelayanan kepada nasabah".

Berdasarkan Analisis Regresi Linear Berganda, nilai koefisien regresi Kompetensi $\left(\mathrm{X}_{2}\right)$ adalah sebesar 0,141 dan menunjukkan arah koefisien regresi positif (searah) antara Kompetensi dan Produktivitas Kerja. Artinya setiap kenaikan 1 satuan Kompetensi dan variabel lain dianggap konstan, akan meningkatkan Produktivitas Kerja sebesar 0,141 satuan.

3. Pengaruh Upah terhadap Produktivitas Kerja Karyawan di PT BPRS Bandar Lampung

Berdasarkan teori menurut Mohammad Kanzunnudin upah merupakan suatu penerimaan sebagai imbalan dari pimpinan perusahaan kepada tenaga kerja untuk suatu pekerjaan atau jasa yang telah dan akan 
dilakukan. Tingkat upah yang masih sangat rendah akan mempengaruhi usaha peningkatan produktivitas tenaga kerja. Sebaliknya tingkat produktivitas yang sangat rendah sulit untuk menjamin naiknya upah. Tinggi rendahnya upah yang diterima oleh para tenaga kerja sangat menentukan tinggi rendahnya tingkat kesejahteraan tenaga kerja, dimana tingkat kesejahteraan tenaga kerja besar pengaruhnya terhadap semangat mereka dalam melaksanakan aktivitas, dan nantinya akan berdampak di produktivitas kerja yang dilakukan karyawan.

Hipotesis ketiga dalam penelitian ini adalah "upah berpengaruh secara signifikan terhadap produktivitas kerja karyawan". Hasil pengujian hipotesis menunjukkan bahwa nilai variabel upah memiliki nilai signifikan 0,000 yang berarti lebih kecil dari 0,05 (sign $<0,05$ ), sehingga dapat disimpulkan bahwa upah berpengaruh signifikan terhadap produktivitas kerja karyawan di PT BPRS Bandar Lampung dan Haz diterima. Hasil penelitian ini sejalan dengan penelitian yang dilakukan oleh Osvaldo W. Turangan, Christoffel Kojo dan Christoffel Mintardjo, yang menyatakan bahwa pemberian upah berpengaruh positif dan signifikan terhadap produktivitas kerja pegawai (Osvaldo W. Turangan, Christoffel Kojo dan Christoffel Mintardjo, 2017 : 3008-3017). Selain itu, penelitian ini sejalan dengan penelitian yang dilakukan oleh (Astuti, 2017), (Sulaeman, 2014) dan (Santosa et al., 2015) yang menyatakan bahwa upah berpengaruh positif dan signifikan terhadap produktivitas kerja karyawan. Dengan demikian, untuk meningkatkan produktivitas karyawan, perusahaan dapat melakukan sistem pengupahan yang lebih menstimulus peningkatan jumlah produksi, misalnya perbaikan sistem upah per unit per karyawan, perluasan lokasi pemasaran sehingga dapat meningkatkan pesanan dan pada akhirnya akan meningkatkan produksi dan keuntungan perusahaan.

Hasil penelitian ini bertolak belakang dengan penelitian yang dilakukan oleh (Rampisela \& Lumintang, 2020) yang menyatakan bahwa upah berpengaruh negatif signifikan terhadap produktivitas kerja 
karyawan. Hal ini dikarenakan banyak karyawan yang menyatakan bahwa upah yang mereka terima belum sesuai dengan pekerjaan yang mereka lakukan, sehingga faktor ini bisa disimpulkan menjadi penyebab upah tidak berpengaruh terhadap produktivitas kerja karyawan.

PT BPRS Bandar Lampung dalam memberikan upah di karyawan telah cukup baik diterapkan. Hal ini dibuktikan dengan sistem pemberian upah yang dilakukan secara terbuka, sesuai dengan kinerja dan penggolongan senioritas. Tentunya dengan sistem upah yang baik ini akan berdampak pada kinerja karyawan yang terus produktif.

Berdasarkan pada kuesioner yang telah dibagikan peneliti kepada pimpinan dan karyawan PT BPRS Bandar Lampung, sebagian besar responden sudah mendapatkan upah yang sudah sesuai dengan hasil kerja dan sesuai dengan UMP Lampung dan UMK Kota Bandar Lampung.

Berdasarkan Analisis Regresi Linear Berganda, nilai koefisien regresi Upah $\left(X_{3}\right)$ adalah sebesar 0,653 dan menunjukkan arah koefisien regresi positif (searah) antara Upah dan Produktivitas Kerja. Artinya setiap kenaikan 1 satuan Upah dan variabel lain dianggap konstan, akan meningkatkan Produktivitas Kerja sebesar 0,653 satuan.

4. Pengaruh Lingkungan Kerja terhadap Produktivitas Kerja Karyawan di PT BPRS Bandar Lampung

Pengertian lingkungan kerja di sini adalah sesuatu yang ada di sekitar para pekerja dan yang dapat mempengaruhi dirinya dalam menjalankan tugas-tugas yang dibebankan, misalnya kebersihan, musik, penerangan dan lain- lain (Danang Sunyoto, 2012 : 43). Lingkungan kerja sangat berperan penting dalam menciptakan suatu dorongan kepada karyawan agar dapat bekerja lebih baik dalam mencapai tujuan perusahaan. Meskipun lingkungan kerja tidak melaksanakan proses operasional dalam suatu perusahaan, namun lingkungan kerja mempunyai pengaruh langsung terhadap para karyawan yang melaksanakan kegiatan operasional di perusahaan. 
Hipotesis keempat dalam penelitian ini adalah "lingkungan kerja berpengaruh secara signifikan terhadap produktivitas kerja karyawan". Hasil pengujian hipotesis menunjukkan bahwa nilai variabel kompetensi memiliki nilai signifikan 0,046 yang berarti lebih kecil dari 0,05 (sign < 0,05), sehingga dapat disimpulkan bahwa lingkungan kerja berpengaruh signifikan terhadap produktivitas kerja karyawan di PT BPRS Bandar Lampung dan $\mathrm{Ha}_{4}$ diterima. Hasil penelitian ini sejalan dengan penelitian yang dilakukan oleh Imron Mashudi, Ratna Wijiyanti, dan Bahtiar Efendi yang menyatakan hasil bahwa Lingkungan Kerja sebagai variabel bebas berpengaruh positif dan signifikan terhadap Kinerja kerja Karyawan PT Bank BRI Tbk. Kantor Cabang Kabupaten Wonosobo (Imron Mashudi, Ratna Wijiyanti, dan Bahtiar Efendi, 2020: 319-325).

Selain itu, penelitian lain yang juga sejalan dengan penelitian ini antara lain penelitian oleh (Sofyan, 2013), (Rahmawanti et al., 2014), (Panjaitan, 2017) dan (Maya et al., 2015) yang menyatakan bahwa lingkungan kerja berpengaruh secara positif dan signifikan terhadap produktivitas kerja. Hal tersebut berarti bahwa lingkungan kerja di suatu perusahaan dapat memengaruhi produktivitas kerja karyawan, sehingga untuk meningkatkannya, maka perusahaan harus memiliki lingkungan kerja yang kondusif.

Lingkungan kerja di PT BPRS Bandar Lampung sudah cukup baik dalam menunjang produktivitas kerja karyawan. Hal ini sesuai dengan hasil wawancara dengan Bapak Marsono, S.E selaku Wakil Direktur PT BPRS Bandar Lampung. Berdasarkan hasil wawancara tersebut, peneliti mendapatkan keterangan bahwa lingkungan kerja di PT BPRS Bandar Lampung sudah cukup baik, bila dilihat dari indikator kondisi kerja dan perlengkapan kerja. Kondisi kerja di PT BPRS Bandar Lampung sudah memiliki ruang, suhu, penerangan, dan ventilasi udara yang baik. Dan perusahaan sudah memiliki perlengkapan kerja yang baik dan memadai yang meliputi sarana dan prasarana penunjang kerja, seperti komputer, 
mesin ketik, dan lain-lain. Namun, pada indikator pelayanan kepada pegawai masih ditemukan masalah dan kelemahan yaitu di PT BPRS Bandar Lampung yang belum mempunyai tempat sarana kesehatan untuk para pegawai/karyawan. Sehingga bisa mengakibatkan penurunan produktivitas kerja di karyawan.

Berdasarkan Analisis Regresi Linear Berganda, nilai koefisien regresi Lingkungan Kerja $\left(\mathrm{X}_{4}\right)$ adalah sebesar -0,197 dan menunjukkan arah koefisien regresi negatif (berlawanan searah) antara Lingkungan Kerja dan Produktivitas Kerja. Artinya setiap kenaikan 1 satuan Lingkungan Kerja dan variabel lain dianggap konstan, akan menurunkan Produktivitas Kerja sebesar -0,197 satuan.

5. Pengaruh Pengendalian Internal, Kompetensi, Upah dan Lingkungan Kerja terhadap Produktivitas Kerja Karyawan di PT BPRS Bandar Lampung

Hipotesis kelima dalam penelitian ini adalah "pengendalian internal, kompetensi, upah dan lingkungan kerja berpengaruh secara signifikan terhadap produktivitas kerja karyawan". Hasil pengujian hipotesis menunjukkan bahwa hasil uji $\mathrm{F}$ diperoleh nilai $\mathrm{F}$ hitung sebesar 47,979 dengan nilai signifikan 0,000 yang berarti nilai signifikansi $<0,05$. Sehingga dapat disimpulkan bahwa pengendalian internal, kompetensi, upah dan lingkungan kerja secara simultan berpengaruh signifikan terhadap produktivitas kerja Karyawan di PT BPRS Bandar Lampung dan $\mathrm{Ha}_{5}$ diterima. Hasil penelitian ini sejalan dengan penelitian yang dilakukan oleh Siliatang Aksinapang, Syamsul Bachri dan Idris Azis yang menyatakan hasil bahwa kompetensi, kompensasi dan lingkungan kerja non fisik secara simultan berpengaruh positif dan signifikan terhadap kinerja pegawai PT Bank Negara Indonesia (Persero) Tbk. Kantor Cabang Utama Palu (Siliatang Aksinapang, Syamsul Bachri dan Idris Azis, 2018 : 182-194).

PT BPRS Bandar Lampung telah konsisten dalam melakukan pengendalian internal untuk terus memantau kinerja karyawannya. Hal ini dilakukan dengan tujuan karyawan mampu untuk melaksanakan tugas 
dengan rapi dalam bidang yang karyawan kerjakan. Juga harus memastikan karyawan memiliki kemampuan yang sesuai dengan standar perusahaan. Tentunya nanti akan berdampak pada kinerja yang produktif untuk perusahaan.

Selain itu, kompetensi dan upah menjadi faktor utama karyawan untuk bekerja lebih produktif. Apabila perusahaan memiliki kompetensi karyawan yang baik akan menghasilkan pekerjaan yang efisien dan tepat waktu. Dan perusahaan memberikan upah yang sesuai bahkan lebih dari kinerja yang karyawan berikan di perusahaan, tentunya akan meningkatkan semangat kerja pada karyawan. Dimana kedua faktor ini menjadi sangat penting agar karyawan mampu mencapai target yang perusahaan berikan.

Lingkungan kerja juga sangat berpengaruh pada produktivitas kerja karyawan. Lingkungan yang baik tentunya akan menunjang kinerja karyawan, baik itu dari fasilitas yang diberikan perusahaan ataupun hubungan yang baik dan harmonis antar karyawan dan atasan. Lingkungan kerja yang positif akan mampu meningkatkan kepercayaan diri dan mutu karyawan sehingga kinerja yang diberikan menjadi lebih produktif.

\section{KESIMPULAN}

Penelitian ini bertujuan untuk melihat pengaruh pengendalian internal, kompetensi, upah dan lingkungan kerja terhadap produktivitas kerja perusahaan entitas syariah. Penelitian ini menggunakan analisis regresi linear berganda sebagai teknik analisis hipotesis dengan menggunakan program IBM Statistik SPSS 17. Berdasarkan hasil pengujian hipotesis pada penelitian ini, maka dapat disimpulkan sebagai berikut :

Variabel pengendalian internal berpengaruh signifikan terhadap produktivitas kerja karyawan PT BPRS Bandar Lampung. Sesuai dengan hasil regresi secara parsial (uji T) dengan menghasilkan nilai signifikan 0,020 yang berarti lebih kecil dari 0,05 (sign < 0,05). PT BPRS Bandar Lampung memiliki komite pengawas baik internal maupun eksternal yang bertugas memberi 
rekomendasi atau saran dan mengawasi jalannya kinerja operasional PT BPRS Bandar Lampung. Selain itu, juga sudah ada SOP yang mengatur segala hal untuk menghindari berbagai tindakan fraud yang bisa terjadi dan juga dapat mendukung kinerja PT BPRS Bandar Lampung. Dan berdasarkan Analisis Regresi Linear Berganda, nilai koefisien regresi Pengendalian Internal $\left(\mathrm{X}_{1}\right)$ adalah sebesar 0,409 dan menunjukkan arah koefisien regresi positif (searah) antara Pengendalian Internal dan Produktivitas Kerja. Artinya setiap kenaikan 1 satuan variabel Pengendalian Internal dan variabel lainnya dianggap konstan maka akan menaikkan nilai Produktivitas Kerja sebesar 0,409.

Variabel kompetensi berpengaruh signifikan terhadap produktivitas kerja karyawan PT BPRS Bandar Lampung. Sesuai dengan hasil regresi secara parsial (uji T) dengan menghasilkan nilai signifikan 0,003 yang berarti lebih kecil dari 0,05 (sign < 0,05). PT BPRS Bandar Lampung sudah baik dalam memberikan pelayanan dengan selalu memberikan senyum pada nasabah, baik secara pengetahuan sehingga dapat membantu nasabah yang meminta pelayanan dan nasabah juga tidak gugup dalam memberikan pelayanan. Dan berdasarkan Analisis Regresi Linear Berganda, nilai koefisien regresi Kompetensi $\left(\mathrm{X}_{2}\right)$ adalah sebesar 0,141 dan menunjukkan arah koefisien regresi positif (searah) antara Kompetensi dan Produktivitas Kerja. Artinya setiap kenaikan 1 satuan Kompetensi dan variabel lain dianggap konstan, akan meningkatkan Produktivitas Kerja sebesar 0,141 satuan.

Variabel upah berpengaruh signifikan terhadap produktivitas kerja karyawan PT BPRS Bandar Lampung. Sesuai dengan hasil regresi secara parsial (uji T) dengan menghasilkan nilai signifikan 0,000 yang berarti lebih kecil dari 0,05 (sign < 0,05). PT BPRS Bandar Lampung dalam memberikan upah di karyawan telah cukup baik diterapkan. Hal ini dibuktikan dengan sistem pemberian upah yang dilakukan secara terbuka, sesuai dengan kinerja dan penggolongan senioritas. Tentunya dengan sistem upah yang baik ini berdampak pada kinerja karyawan yang terus produktif. Dan berdasarkan Analisis Regresi Linear Berganda, nilai koefisien regresi Upah $\left(X_{3}\right)$ adalah 
sebesar 0,653 dan menunjukkan arah koefisien regresi positif (searah) antara Upah dan Produktivitas Kerja. Artinya setiap kenaikan 1 satuan Upah dan variabel lain dianggap konstan, akan meningkatkan Produktivitas Kerja sebesar 0,653 satuan.

Variabel lingkungan kerja berpengaruh signifikan terhadap produktivitas kerja karyawan PT BPRS Bandar Lampung. Sesuai dengan hasil regresi secara parsial (uji T) dengan menghasilkan nilai signifikan 0,046 yang berarti lebih kecil dari 0,05 (sign < 0,05). Lingkungan kerja digunakan sebagai salah satu penunjang kinerja karyawan. Sarana dan prasarana sangat efektif untuk digunakan sebagai penunjang produktivitas kerja karyawan. Pastinya dengan adanya perlengkapan kerja yang baik dan memadai bisa dapat membantu pekerjaan karyawan. Sehingga dapat meningkatkan kinerja dan produktivitas kerja karyawan. Akan tetapi masih ada yang harus diperbaiki yaitu dari segi tempat Sarana Kesehatan untuk para karyawan yang harus dipenuhi oleh perusahaan. Dan berdasarkan Analisis Regresi Linear Berganda, nilai koefisien regresi Lingkungan Kerja $\left(\mathrm{X}_{4}\right)$ adalah sebesar -0,197 dan menunjukkan arah koefisien regresi negatif (berlawanan searah) antara Lingkungan Kerja dan Produktivitas Kerja. Artinya setiap kenaikan 1 satuan Lingkungan Kerja dan variabel lain dianggap konstan, akan menurunkan Produktivitas Kerja sebesar 0,197 satuan.

\section{IMPLIKASI PENELITIAN}

Implikasi penelitian yaitu kompetensi karyawan dalam suatu lembaga haruslah baik sesuai nilai-nilai islam yaitu karyawan harus amanah dan jujur dalam bekerja memiliki hubungan yang baik antara atasan dan bawahan. Sehingga hal-hal tersebut dapat meningkatkan produktivitas kerja karyawan.

\section{REFERENSI}

Ardiansyah, Y., \& Sulistiyowati, L. H. (2018). Pengaruh Kompetensi dan Kecerdasan Emosional Terhadap Kinerja Pegawai. 2(1), 91-100. 
Arifiyani, H. A., \& Sukirno. (2012). Pengaruh Pengendalian Intern, Kepatuhan dan Kompensasi Manajemen terhadap Perilaku Etis Karyawan (Studi Kasus PT Adi Satria Abadi Yogyakarta). Jurnal Nominal, 1(1), 5-21.

Astuti, E. A. (2017). Pengaruh Upah dan Insentif terhadap Produktivitas Kerja Karyawan. Jurnal Manajemen Dan Kewirausahaan, 2(1), 33-43.

Bazighoh, N., \& Sari, S. P. (2019). Pengaruh Kompensasi, Pengalaman Kerja, Penggunaan Sistem Informasi Akuntansi dan Pemahaman tentang Pengendalian Internal terhadap Kinerja Karyawan. Seminar Nasional Dan The 6th Call for Syariah Paper (SANCALL), 1068-1076.

Maya, M., Mandey, S., \& Tumade, P. (2015). Analisis disiplin, kompensasi, lingkungan kerja, pengaruhnya terhadap produktivitas kerja karyawan di pt. pln (persero) wilayah suluttenggo. Jurnal EMBA: Jurnal Riset Ekonomi, Manajemen, Bisnis Dan Akuntansi, 3(1), 726-736.

Panjaitan, M. (2017). Pengaruh Lingkungan Kerja Terhadap Produktivitas Kerja Karyawan. Jurnal Manajemen, 3(2), 1-5.

Pramularso, E. Y. (2018). Pengaruh Kompetensi terhadap Kinerja Karyawan CV Inaura Anugerah Jakarta. Widya CIpta, 11(1), 40-46.

Prayogi, M. A., Lesmana, M. T., \& Siregar, L. H. (2019). Pengaruh Kompetensi Dan Disiplin Kerja Terhadap Kinerja Pegawai. Prosiding FRIMA (Festival Riset Ilmiah Manajemen Dan Akuntansi), 2, 665-670.

Putri, P. A. Y., \& Endiana, I. D. M. (2020). Pengaruh Sistem Informasi Akuntansi dan Sistem Pengendalian Internal terhadap Kinerja Perusahaan (Studi Kasus pada Koperasi di Kecamatan Payangan). Krisna: Kumpulan Riset Akuntansi, 11(2), 179-189.

Rahmawanti, N. P., Swasto, B., \& Prasetya, A. (2014). ( Studi pada Karyawan Kantor Pelayanan Pajak Pratama Malang Utara ). Jurnal Administrasi Bisnis, $8(2), 1-9$.

Rampisela, V. A. J., \& Lumintang, G. G. (2020). Pengaruh Motivasi Kerja, Lingkungan Kerja dan Upah terhadap Produktivitas Kerja Karyawan PT Dayana Cipta. Jurnal EMBA: Jurnal Riset Ekonomi, Manajemen, Bisnis Dan 
Akuntansi, 8(1), 302-311.

Risnawati, H., \& Retnoningsih, S. (2020). Pengaruh Pemberian Insentif, Pelatihan Kerja dan Pengendalian Intern terhadap Efektivitas Kinerja Karyawan. PERMANA: Jurnal Perpajakan, Manajemen Dan Akuntansi, 12(2), 137-152.

Rosmaini, \& Tanjung, H. (2019). Pengaruh Kompetensi, Motivasi Dan Kepuasan Kerja Terhadap Kinerja Pegawai. Jurnal Ilmiah Magister Manajemen, 2(1), 115.

Santosa, S. T., Hidayat, W., \& Nurseto, S. (2015). Pengaruh Lingkungan Kerja, Motivasi Kerja dan Upah terhadap Produktivitas Kerja (Studi Kasus pada Karyawan Bagian Produksi Perum Perhutani Industri Kayu Brumbung). Jurnal Ilmu Administrasi, 4(4), 114-121.

Saputra, I. P. A., Bagia, I. W., \& Suwendra, I. W. (2016). Pengaruh Kompetensi dan Disiplin Kerja terhadap Kinerja Karyawan. E-Journal Bisma Universitas Pendidikan Ganesha, 4(1).

Sofyan, D. K. (2013). Pengaruh Lingkungan Kerja Terhadap Kinerja Kerja Pegawai BAPPEDA. Malikussaleh Industrial Engineering Journal (MIEJ), 2(1), $18-23$.

Sulaeman, A. (2014). Pengaruh Upah dan Pengalaman Kerja terhadap Produktivitas Karyawan Kerajinan Ukiran Kabupaten Subang. Jurnal Ekonomi Trikonomika, 13(1), 91-100.

Sunarty, N. (2015). Pengaruh Pengendalian Intern, Gaya Kepemimpinan, Lingkungan Kerja dan Disiplin Kerja terhadap Kinerja Karyawan Bagian Akuntansi dan Keuangan pada Bank BPR Kepri Bintan dan BPR Bintan. Jurnal Akuntansi, 6(2), 126-140.

Suwarto, \& Suharto. (2014). Analisis Kemampuan Penggerakan Pimpinan dan Pengendalian Internal dengan Peningkatan Produktivitas Kerja Pegawai pada Kantor Dinas Tata Kota dan Pariwisata Kota Metro. Derivatif, 8(1), 1833.

Syahputra, M. D., \& Tanjung, H. (2020). Pengaruh Kompetensi, Pelatihan dan 
Pengembangan Karir Terhadap Kinerja Karyawan. 3(2), 283-295.

Alex S. Nitisemito. Manajemen Personalia. Jakarta: Ghalia Indonesia, 2015.

Alvin A. Arens, Randal J. Elder, dan Mark S. Beasley. Auditing E Jasa Assurance Pendekatan Terintegrasi. Jakarta : Penerbit Erlangga, 2015.

Askimin Zainal, Dasar - Dasar Hukum Perburuhan. Jakarta: Raja Grafindo, 2006.

Budi Rismayadi, “Faktor-Faktor Yang Mempengaruhi Produktivitas Karyawan

(Studi Kasus pada CV Mitra Bersama Lestari Tahun 2014)". Jurnal Manajemen E Bisnis ISSN 2528-0597 1 No, 1 (2015).

Danang sunyoto. Teori Kuesioner, Dan Analisis Data Manajemen Sumber Daya Manusia. Yogyakarta: CAPS, 2012.

Dini Widyawati dan Putri Nurmala, "Pengaruh Internal Audit, Sistem

Informasi Akuntansi Dan Sistem Pengendalian Internal Terhadap Kinerja Karyawan (Studi Empiris pada PT BPRS Al Salaam Amal Salman)", Jurnal 16 No. 2 (2019).

Edy Sutrisno. Manajemen Sumber Daya Manusia. Jakarta : Kencana Prenada Media Group, 2016.

Falentina K. G. Rani, Linda Lambey, dan Sherly Pinatik, “Pengaruh Integritas, Kompetensi, dan Profesionalisme Terhadap Produktivitas Kerja Karyawan Bagian Akuntansi Pada PT Bank Mandiri (Persero) Tbk Manado", Jurnal Riset Akuntansi Going Concern 13 Nomor 3 (2018).

Hery. Pengendalian Akuntansi Dan Manajemen. Jakarta : Kencana, 2014.

Hiro Tugiman. Standar Profesional Audit Internal. Yogyakarta : Kanisius, 2006. Imron Mashudi, Ratna Wijiyanti, dan Bahtiar Efendi, “Pengaruh Motivasi Kerja,

Kedisiplinan Kerja dan Lingkungan Kerja Terhadap Kinerja (Studi Kasus pada Karyawan PT Bank BRI Tbk. Kantor Cabang Kabupaten Wonosobo)”, Journal of Economic, Business and Engineering (JEBE) 1, No. 2 (2020).

Jerry M. Logahan, “Analisis Lingkungan kerja dan Pemberian Kompensasi Terhadap Kinerja karyawan CV Mum Indonesia", Jurnal 3 No.1 (2012). 
Kementerian Agama RI. Al-Quran Tajwid dan Terjemahannya Dilengkapi dengan Asbabun Nuzul dan Hadits Sahih, Q.S Al-Jumuah : 10. Bandung : PT Sygma Examedia Arkanleema, 2017.

Khoirul Fathoni dan Mohammad Ghozali, "Analisis Konsep Produktivitas Kerja Konvensional dalam Pandangan Islam", Jurnal: Al- Tijarah 3, No. 1 (2017).

Laporan Keuangan Publikasi PT BPRS Bandar Lampung. Http://www.banksyariahbandarlampung.co.id, diakses pada tanggal 28 Mei 2021.

Mohammad Kanzunnudin, "Pengaruh Upah dan Pengawasan Terhadap Produktivitas Karyawan Studi Kasus Pada PT Tonga Tiur Putra Kragan Kabupaten Rembang", Jurnal Fokus Ekonomi 2 No. 1 (2017).

Nico, "Pengaruh Semangat Kerja Dan Upah Terhadap Kinerja Perawat RSU Sarah Medan", (Skripsi, Universitas Medan Area, 2018).

Osvaldo W. Turangan, Christoffel Kojo dan Christoffel Mintardjo, “Upah Dan Insentif Terhadap Produktivitas Kerja Pegawai Kantor Badan Penanggulangan Bencana Daerah Provinsi Sulawesi Utara", Jurnal (2017).

Riawati,dkk, “Analisis Pengaruh Kepemimpinan, Motivasi Kerja Dan Pelatihan Kerja Terhadap Kinerja Karyawan". Jurnal Progresif Manajemen Bisnis (JIPMB) 12, No. 2 (2016).

Siliatang Aksinapang, Syamsul Bachri dan Idris Azis, "Pengaruh Kompetensi, Kompensasi Dan Lingkungan Kerja Non Fisik Terhadap Kinerja Pegawai Pada PT Bank Negara Indonesia (Persero) Tbk Kantor Cabang Utama Palu", e-Jurnal Katalogis 6 No. 4 (2018).

Sumbulatin Miatuhabbah, “Analisis Sistem Pengendalian Intern Pada Sistem Penggajian Di Baitul Mal Wat Tamwil (Bmt) An-Nur Rewwin Waru Sidoarjo", (Skripsi, Universitas Islam Negeri Sunan Ampel, 2018).

Tri Wikaningrum, “Praktek Dan Kebijakan Manajemen Sumber Daya Manusia Pada Perbankan Syariah", Jurnal 15 No. 1 (2011). 
Wibowo. Manajemen Kinerja, Edisi Kelima, Cetakan Ke-12. Depok : PT Raja Grafindo Persada, 2017.

Wiratna Sujarweni. Sistem Akuntansi. Yogyakarta : Pustaka Baru Press, 2015 